\title{
Critical Thinking and Autonomy in Speaking Ability: A Case Study
}

\author{
Najme Bagheri* \\ Department of English Language, Marvdasht Branch, Islamic Azad University, Marvdasht, Iran
}

*Corresponding Author: Najme Bagheri, Department of English Language, Marvdasht Branch, Islamic Azad University, Marvdasht, Iran

\begin{abstract}
This study investigated the relationship between autonomy and critical thinking in speaking ability among EFL students at Islamic Azad university of Shiraz. To this aim, three types of instruments were applied to collect research data, i.e. Zhang and li's learner autonomy questionnaire, Watson-Glaser Critical Thinking Appraisal as well as a final achievement exam administered at the end of the term to collect students' English speaking grades. For the analysis of the data, correlation method was employed. Significance level of 0.05 was considered for testing the hypotheses. The findings indicated that there was a significant relationship between speaking ability and autonomy. Also, there was a positive relationship between speaking ability and critical thinking .In fact, those English learners who were recognized as critical thinkers and autonomous performed better in their oral production.
\end{abstract}

Keywords: Autonomy, Critical Thinking, Speaking Ability.

\section{INTRODUCTION}

For effective communication, EFL and ESL students need to improve their oral skills. At first glance, EFL / ESL students usually value their ability to speak. Teaching and learning are often considered a difficult and intense task. Although the speech is an important skill, sometimes overlooked (Snow, 2012). Broad research has been done to determine the relationship between oral competence and other areas of education.

As described by Willingham (2007), one of the main objectives of school education is to teach critically minded students, including examining both sides of the problem, to be opened for confirmation, rejecting your ideas and the right to approval. Observation, induction, and reasoning of the evidence. For scholars, critical thinking can be defined as psychological and cognitive activities. It is a set of three ideas: reasoning, decision-making and judgment, and problem-solving.

Warnick and Inch (1994) define critical thinking as "ability to investigate problems, problems or situations, integrate all available information, suggest solutions or assumptions, and confirm your position." (page 11).

According to Arum and Roska (2011), "99\% of teachers believe that developing critical thinking skills is a very important or indispensable goal for university education" (page 11). According to Facione (2007), intelligent and cognitive abilities and skills can be the core of critical thinking, including interpretation, analysis, evaluation, reasoning, interpretation, and self-regulation. The explanation includes the understanding and understanding of the specific circumstances of the standard, experience, evidence, thoughts, data, rules and regulations, processes and procedures, as well as meaning or meaning. Interpretation of meaning, classification, and expression, explanation of meaning is a means of interpretation (Facione, 2007). Analysis can be defined as a practical and intentional combination of concepts, ideas, beliefs, problems, events or experiences. Identifying ideas, differentiating disputes and analyzing them as assisted analytical skills (Facione, 2007). The assessment is based on the perspectives, circumstances, and judgments of the individual to investigate the reliability and reliability of statements or testimonies and to determine logical and rational relations between different statements in different situations (Facione, 2007). Reason means differentiating and applying characteristics and characteristics to draw conclusions, hypothesis suggestions, finding relevant information, and obtaining data, experiences, statements, and results related to the situation. To find evidence, give opinions and draw conclusions are the basic techniques 
of reasoning (Facione, 2007). Facione (2007) believes that interpretation can be defined as an excuse in a logical and meaningful way and expressing a complete picture and observation of the whole event and evidence. The sub-skills in the explanation are the methods and the results of the expression, the logic behind the interpretation process, the logic and the reasons behind the support issues.

Facione (2007) also stressed that self-regulation uses different skills to analyze, evaluate and evaluate the work, control, and monitoring of their mental activity and cognitive abilities and attributes that apply to these activities, to ask questions, to test results or to argue the verification. trial. Teachers believe that speaking skills are the most important part of the EFL curriculum. By improving the technology and the need for community interaction, many students take part in language courses to improve their speaking skills. Pupils who have higher social experiences and communicate with others are more successful in speaking skills (Malmir \& Shoorchech, 2012).

Accuracy and fluency are two important factors that determine the success or failure of prospective English students. Accuracy is the ability to use grammar and accurate vocabulary to generate accurate sentences. Accuracy is relative. Early children and adults cannot reach the same level of accuracy. Teachers who appreciate accuracy can help their students produce grammatically correct written and spoken language. Skills mean relaxation, fluency, and expression. In other words, the speaker can be clear and concise, easily responding to a language and linking meaning to the context (Malmir \& Shoorchech, 2012). According to Folse (2006), the ability to speak in one language makes most people synonymous with the recognition that language is the most basic way of human communication.

With the decline of audiolingualism in the 1970s, interest has shifted from the focus of methodology and educational practice to the role of individuals as students. Since 1970, the study of anthropology and communication methods reflects this point on the development of language learning and the study of students' styles and strategies (Hall, 2011). During this period, teachers and teachers turned to the lesson and learners, and the characteristics of the students paid more attention. This leads to finding good language learners and analyzing their learning styles and strategies to teach those less successful learners. Since then, the concept of autonomy of language learners has become an important feature of good language learners in ELT literature. Many scholars studied and studied the concept of autonomy. Holek, however, can be considered as the father of this concept because he created this word in 1981 and wrote a lot. Different scholars have proposed many definitions of this term. Holek himself (1981, p. 3) defines autonomy as "the ability to control his teaching". Nunan $(2003,290)$ also defines autonomy as "the ability to manage his learning". To explain the exact meaning of "responsibility" in the context of learning, Benson (2001) described students independently as their ability to control his teaching, mainly because the "control" structure looks more like " tax ". Or the "liability" structure is more open. Faerch and Casper (1983, p. 56) argued that "student autonomy can be considered as the ability to overcome the gap between pedagogical and non-educational communication situations".

\subsection{Statement of the Problem}

Whenever people understand what they need in a logical and reflective way they must work hard to find a reasonable solution to solve complex problems and to analyze the methods and conditions for fulfilling scientific hypotheses. Using and applying critical thinking skills, students' ability to autonomy and speech can be significantly improved. The speaker played a more active role in the speech and tried to understand and make decisions in a difficult environment (Malmir \&Shoorchech, 2012). Students do not have enough time to ask questions or to share ideas in the classroom. Therefore, the teacher curriculum should be prepared within a limited time and be covered by the teacher. It should not be able to publish freely and uncover some of the system's shortcomings. In such cases, people can understand the material properly, get meaning from the surface in different dialogues, draw logical conclusions and put relevant questions in the classroom within a limited time. Thus, we can say that improving the language skills of this system is of utmost importance.

Therefore, participation in discussions for a better and better judgment and the difference between different situations is an active or critical element of thinkers and self-management. This can lead to student participation at Syrah Azad University, Iran, in class discussions, and willingness to ask questions (for example, speaking). Critical thinkers' answers are a good way for other students to better understand and build different ideas, and ultimately to succeed in international communication (Malmir \& Shoorchech, 2012). 
Although various researchers undergo various field studies, such as Malmir and Shoorcheh (2012) and Sanavi and Tarighat (2014), they accepted critical thinking and other concepts and capabilities in TEFL or any possible relationship. impact. It can express the basic aspects of English teaching.

My studies focused on the relationship between student autonomy and language ability (see Dafei, 2007). For example, Ablard and Lipschultz (1998) found that some senior students came up with different autonomous strategies. Corno and Mandinach (1983) emphasized that student autonomy could help improve student language skills and conclude that autonomous students are high school students. Risenberg and Zimmerman (1992) point out that high student autonomy with high success rates achieves high scores, while students with low autonomous students (such as student autonomy can improve their academic performance) may have low scores. risk.

Many English students cannot speak fluently and accurately. The purpose of this study is to improve the oral English speaking skills of Azad University students and their relationship with critical thinking and autonomy.

\subsection{Research Question and Hypothesis}

Q1: Is there any relationship between autonomy and speaking ability among Iranian EFL learners?

Q2: Is there any relationship between critical thinking and speaking ability among Iranian EFL learners?

H01: There is no relationship between autonomy and speaking ability among Iranian EFL learners.

H02: There is no relationship between critical thinking and speaking ability among Iranian EFL learners.

\subsection{Purpose of the Study}

The purpose of this study is to provide insights into the critical thinking, autonomy, and speaking skills of students at the Shiraz University at the Islamic Azad University. Being a critical thinker and autonomy is very important for students studying at the University of Shiraz, because it may lead students to participate in discussions, ask more questions, make better and faster decisions, and eventually become short Get more benefits in time and short time. In addition, feedback from critical thinkers may have a positive impact on other students in order to play a more active role in their speeches. Therefore, this study aims to determine the relationship between critical thinkers and autonomy of speech.

\section{LITERATURE REVIEW}

\subsection{A Brief History of the Idea of Critical Thinking}

According to Paul, Elder, and Bartel (1997), the roots of critical thinking can be traced 2500 years ago to Socrates's methods and concepts. They discovered and questioned people through their teaching practices that could not logically support their differences. The idea of the idea. He emphasized the importance of the deeper question before people accepted any thought to make people think. Asking, follow the evidence to apply the argument, carefully study the main assumptions and concepts, and conclude that it was founded by Socrates. His teaching practice and investigation-based methods, now called "Socratic Questions," are the most popular critical thinking strategies and techniques.

Plato, Aristotle, and Greek scholars follow Socrates's methods and ideas, often different from what they suggested. Only educated people can understand the truth of things. Based on these traditions, those who want to know deeper fields should think logically and systematically to discover the effects of magic squares in a profound and accurate way because the only way to go beyond the surface is square magic. Comprehensive, rational, including and responding to disagreements (Paul, Elder, and Bartell, 1997).

The idea of systematic critical thinking is reflected in the works of the medieval Thomas Aquinas. The ability to justify it and the need to justify the system were all authorized. Based on Aquinas' opinion, critical thinkers do not always leave ruled or established ideas, but only those who incorporate logic. Since the Renaissance (15th and 16th centuries), he thought critically about different issues, situations and problems in religion, art, humanism, and society and began to think systematically. 
In England, Francis Bacon clearly showed the key to systematic thinking and empirical cosmic research in his book The Learning Process. He provoked bad ideas (idols) and urged people to believe what was false or misleading. Descartes wrote the second article in critical thinking, called fifty years later French ideological rule. It protects and protects the need for clear and accurate ideas and develops methodologies of thinking based on systematic skepticism. This means that every aspect of thought and thought should be questioned, suspected and tested. "I Think So I" is Dekart's famous term and emphasizes the importance of using clever ways to think (Paul, Elder, and Bartell, 1997).

Critical thinking exercises have a wide range of impacts on everyday human life. The summary of critical thinking shows that the logic and reason for thinking and belief can be ignored is a sort of bias and bias that limits the position and position of a student. Therefore, the inclusion of critical penetration into different evidence is an important prerequisite for rational behavior and knowledge (Paul, 1985).

One of the main objectives of education and education is the ability to think critically. It is therefore important that students be trained with different methods and methods in the field of education around the world (Paul, 1985).

Adequate content knowledge is one of the prerequisites for critical thinking skills. If the pupil knows little about the subject, he can not criticize the evidence. In this case, he will apply the topic to find the best solution (Willingham, 2007). As mentioned above, some critical thinking studies are being done and try to determine the links between different skills and this concept. In studying this concept, the studies of Malmir and Shoorcheh (2012) and Sanavi and Tarighat (2014) are the most important for this study. However, current research is different in some respects. It is to explain the relationship between critical thinking and oral autonomy and how links and possible links between two concepts influence and facilitate the learning process. A related study was conducted at Azad Islamic University in Shiraz.

\subsection{Speaking Skills}

Oral language seems to be the most critical skill in all language skills because the language leader is the representative of a language user, just like any other language, including listening, reading, and writing. Zhong (Ur, 1996). When they speak, people can know how many languages they know and how many of them can display correct grammar, vocabulary, and so on. Therefore, spoken language can cover other language skills and it is necessary to improve in a good way. Oral skills can be defined as the most important part of the EFL curriculum. With the advancement of technology and the need for international exchanges in the contemporary world, language learners take part in language courses to improve their speaking skills. Those who interpret more will achieve more success and efficiency in schools and other areas of life (Malmir \& Shoorcheh, 2012). According to Folse (2006), most people think that language recognition means a language because the word is a basic element of communication with other people in society but can provide a language for foreign language learners. Very difficult because verbal communication should be able to use the language correctly in social communication. Interaction includes not only verbal communication, but languagebased elements such as stress, intonation, and intonation (Seligson, 1997, Fulcher, 2003). Verbal and oral communication involves writing and negotiating languages in different ways. Speakers and listeners speak the language of production and processing in language interactions, but both skills are very sensitive and highly dependent on time, which means that they must treat the language in words without any possibility of return, inspection, and production. The speaker also needs to take into account the relationship with others or the person they hear and communicate and adapt their language (Thornbury, 2007).

Under the skills of the macro language, spoken language is an assessment of the most difficult skills, which means that it is difficult to determine language skills (Joiner \& Jones, 2003). A discussion is an interactive constructive process that involves the production, acquisition, and processing of information (Brown, 1994; Burns \& Joyce, 1997).

The conversation is very dependent on the context in which it happened. Participants, their knowledge, goals, subject experiences, and physical and mental conditions can influence the form and meaning of the word.

Speaking skills and spoken language skills can affect the success of any communication (Van Duzer, 1997). The speaker should be able to anticipate and produce the expected model of a particular 
discourse situation. They also manage discrete elements, such as rotation, rewriting, response, or tracking (Burns \& Joyce, 1997).

According to the Roma (2004), both methods are suitable for identifying and evaluating spoken language skills. The first method is the observation method that evaluates incorrectly and evaluates the behavior and performance of students. In a structured approach, students must perform one or more specific oral communication tasks. Then they saw and praised their work on the mission. This task can be implemented or grouped indirectly. within

In the current study, we used a structured approach to get each student one by one (as mentioned by Malmir \& Shoorcheh, 2012).

\subsection{Learner Autonomy}

Student autonomy is the ability of a student to decide independently and not to be influenced by other people. Dickinson (1995) defines autonomy as the student's attitude to learning. It is the responsibility of students to learn through this attitude. Breeze (2000) also believes that student autonomy is an exploration of attitudes and attitudes experience. Similarly, Little (1995) cited that autonomy is a learning problem and also a learning problem of learning in a formal education environment. Among the many definitions proposed by many scholars, Benson and Foller (1997) believe that autonomy includes five categories, including a variety of skills that can be taught and implemented for autonomous learning, natural skills considered in institutional education and their orientation skin. Student learning situation and student responsibility to teach.

Students need autonomy because teachers do not always guide and help them. Therefore, Nation and Macalists (2010) noted that students need to learn how to learn a language, how to monitor and apply their learning so that they can become effective language learners (page 38). Thanasoulas (2000) noted that motivations, attitudes, needs, learning styles, language learning strategies, and language student awareness are important factors in promoting student autonomy. Many scholars (Dam, 1995, Holec, 1981, Little, 1991) believe that autonomy plays an important role in education. They believe that students with higher autonomy are more motivated to learn and gain knowledge and to have a higher self-esteem of learning.

Arcko (2008) made a study to discover the effect of autonomy on the success of hearing comprehension. Research findings show that there is no significant link between student autonomy and understanding of hearing.

Tabatabaei and Parsafar (2012) study the influence of student autonomy on their ability to think critically. According to research results, autonomous learning has a significant impact on the ability of students to think critically. Fahim and Haghighi (2014) study the relationship between self-criticism and foreign language students thinking skills. Ninety-five EFL students participated in the study. The results show that there is a significant positive relationship between the ability of self-regulation of students and the ability to think critically.

Nosratinia and Zaker (2013) conducted a study to investigate the relationship between the critical thinking and the autonomy of 182 Iranian male and female students. Research findings show that there is a significant positive correlation between critical thinking and participants' autonomy.

\section{Methodology}

It is very important and necessary to say that skills are one of the basic abilities of English students, especially in the TEFL. Researchers encountered many students with poor English. They could not speak accurately and fluently. The purpose of this study was to investigate the interrelationship between critical thinking and autonomy in the oral expression of English-speaking students of the Islamic Azad University in Shiraz in order to clarify its influence on the promotion of oral language skills.

\subsection{Design of Study}

This study is essentially a quantitative study design. The study focused on studying variables that capture these common characteristics and quantifying them by counting, scaling, or assigning values to the classification data. 


\subsection{Participants}

Participants in this study included 100 undergraduate senior university learners, mainly performing TEFL and English translations at Islamic Azad University in Shiraz. Participants almost reached the same level of proficiency that was selected through random sampling (ie, they were both young and old). In addition, the age of the participants was between 19 and 30 years old.

\subsection{Instruments}

For the purpose of research, the following tools were used:

- Autonomous questionnaire

- Critical Thinking Questionnaire

- IELTS speaking test

\subsubsection{Zhang and Li's Learner Autonomy Questionnaire}

The English version of Zhang and Li (2004) Learner Autonomy Questionnaire was used to assess learner autonomy. It is designed based on learning

Oxford (1990), Wendeng (1998) and O'Malley and Chamot (1990) classification strategies. The questionnaire is divided into two parts. The first part contains 11 items and the second part has 10 items in total. The first 11 projects in the Likert scale have five options from less than forever. The second part of the questionnaire used a multiple-choice format in which participants selected answers that were closer to their beliefs and attitudes or ideas. Their choice ranges from A to E ( 1 to 5 points) and participants need to respond within 30 minutes. All items of the instrument are directed, so the range of scores is basically from 21 to 105 . The questionnaire has been proved to have high validity and reliability (Dafei, 2007; Rezaei, Karbalaei and Afraz, 2013). The reliability of the learner's independent questionnaire in this study was estimated to be 0.70 , using the Cronbach alpha coefficient.

\subsubsection{Watson-Glaser Critical Thinking Appraisal}

The second tool used in this study included a critical thinking questionnaire. In order to measure participants' critical thinking level, the Persian version of the Watson-Glaser Critical Thinking Assessment Form (WGCTQ) was used (Watson \& Glasser, 1980). According to McMillan (1987), this questionnaire is the most commonly used measure of critical thinking in post-secondary studies. The scores obtained can predict success and training outcomes in a range of applications and academic settings (Wagner \& Harvey, 2003).

\subsubsection{Speaking IELTS interview}

The third tool is the English final score test, which is administered after the test is completed to collect students' English speaking scores. These grades are quantitative figures collected through interviews with students. This interview was organized and used according to the part of Jincy Jibins teaching IELTS.

\subsection{Data Analysis Procedure}

In order to analyze the collected data, SPSS 22 software (Statistical Package for the Social Science) was run. Pearson's correlation and coefficient of each correlation were calculated to investigate any statistically significant relationship between learners'autonomy and critical thinkingin speaking ability.

\section{Results}

First, the descriptive statistics (i.e. means and standard deviations) of participants' responses to critical thinking questionnaire, autonomy questionnaire, and speaking were calculated (Table 1).

Table1. Descriptive statistics of participants' responses to critical thinking, autonomy questionnaires, and speaking interview

\begin{tabular}{|l|l|l|l|l|l|}
\hline & \multicolumn{1}{|c|}{$\mathbf{N}$} & \multicolumn{1}{|c|}{ Minimum } & Maximum & \multicolumn{1}{|c|}{ Mean } & Std. Deviation \\
\hline Autonomy & 100 & 21.00 & 105.00 & 74.9400 & 29.61191 \\
\hline Critical thinking & 100 & 30.00 & 80.00 & 63.5000 & 15.28616 \\
\hline Speaking & 100 & 2.00 & 10.00 & 7.2600 & 2.23661 \\
\hline Valid N (list wise) & 100 & & & & \\
\hline
\end{tabular}




\subsection{Correlation between Speaking Ability and Autonomy}

In order to answer the main research question, which was "Is there any relationship between autonomy and critical thinking in speaking ability?" the subordinate question had to be answered first.

The first subordinate question was "Is there any relationship between speaking ability and autonomy among EFL learners?" Thus, to determine the relationship between speaking ability and autonomy, a Pearson product moment correlation was applied to data. The results are shown in Table 2.

Table2. The correlation between speaking ability and autonomy

\begin{tabular}{|c|c|c|c|}
\hline & & Autonomy & Speaking \\
\hline \multirow[t]{3}{*}{ Autonomy } & Pearson Correlation & 1 & $.898^{* * *}$ \\
\hline & Sig. (2-tailed) & & .000 \\
\hline & $\mathrm{N}$ & 100 & 100 \\
\hline \multirow[t]{3}{*}{ Speaking } & Pearson Correlation & $.898^{* * *}$ & 1 \\
\hline & Sig. (2-tailed) & .000 & \\
\hline & $\mathrm{N}$ & 100 & 100 \\
\hline
\end{tabular}

** $\mathrm{p}<0.01 * \mathrm{p}<0.05$

As displayed in Table 2, the observed Pearson $\mathrm{R}$ of 0.898 showed a statistically significant relationship between a Pearson's degree of autonomy and speaking ability $(\mathrm{P}=.00<.05)$. This analysis revealed that autonomy had a significant relationship with speaking ability and one with higher autonomy is more successful in his or her speaking ability. Thus the null- hypothesis as there is no relationship between speaking ability and autonomy was rejected.

\subsection{Correlation between Speaking Ability and Critical Thinking}

To determine the relationship between speaking ability and critical thinking, a Pearson product moment correlation was applied to data.

Table3. The correlation between speaking ability and critical thinking

\begin{tabular}{|l|l|l|l|}
\hline \multicolumn{2}{|l|}{ Speaking } & \multicolumn{1}{|c|}{ Speaking } & \multicolumn{1}{c|}{ Critical thinking } \\
\cline { 2 - 4 } & Pearson Correlation & 1 & $.910^{* * *}$ \\
\cline { 2 - 4 } & Sig. (2-tailed) & & .000 \\
\hline \multirow{2}{*}{$\begin{array}{l}\text { Critical } \\
\text { thinking }\end{array}$} & Pearson Correlation & 100 & 100 \\
\cline { 2 - 4 } & Sig. (2-tailed) & $.910^{* * *}$ & 1 \\
\cline { 2 - 4 } & $\mathrm{N}$ & .000 & 100 \\
\hline
\end{tabular}

$* * \mathrm{p}<0.01 * \mathrm{p}<0.05$

As displayed in Table 3, the observed Pearson $\mathrm{R}$ of 0.910 showed a statistically significant relationship between a Pearson's degree of speaking ability and critical thinking $(\mathrm{P}=.00<.05)$. This analysis revealed that speaking ability had significant relationship with critical thinking and one with higher critical thinking is more successful in his/her speaking ability. Thus the null hypothesis as there is no relationship between speaking ability and critical thinking was rejected.

\section{DisCUSSION}

The study explored the relationship between the critical thinking, autonomy and verbal capability of Iranian students of foreign languages. The results further show that there is a positive relationship between the thought and critical speech of the Iranian students in English. The results show that the autonomy and verbal skills of the students of the Iranian students are positively related. This finding is consistent with many previous studies (Dam, 1995, Holec, 1981, Little, 1991), concluding that students of higher autonomy are more motivated to learn and gain knowledge and awareness at a high level. Effective Teaching.

In addition, the results of this study support the findings of Tabatabaei and Parsafar (2012) studies that reveal that autonomous learning significantly impels meaningful thinking skills of students. In addition, this finding is in line with Fahim and Haghighi's (2014) study, which noted that there is an important positive link between self-regulation and critical thinking. This study also supports the results of Nosratinia and Zaker (2013) who reported that there was a significant positive correlation between critical thinking and participants' autonomy. In addition, this study is consistent with the 
Birjandi and Bagherkhazem (2010) study. They found a significant link between the critical critical ability of the student and the professional success of self-esteem. The results of this study are consistent with the results of Myers and Dyer (2006) that found a positive correlation between the critical performance of student thinking and the style of learning. This finding is also consistent with the findings of Nosratinia, Asiabar, and Sarabchian (2014) who found a positive relationship between the critical thinking skills of the participants and their use of language learning strategies. In addition, the study and Barghi and Zangoei (2014) and Fahim and Bolghari (2014) find that there are major differences between the critical critical ability of the learner and the style of communicative learning, the critical critical ability of the learner, and all learning methods. Relationships are between sizes.

Bagheri and Bazrafkan (2014) showed a positive relationship between critical thinking of EFL students and student autonomy, critical thinking and writing ability, student autonomy and skills. This finding is also consistent with the findings of Kias and Larsari and Ramezan (2016) and is an important coefficient of correlation between critical thinking and verbal ability. In addition, this discovery is in line with Rashid and Valad (2014) research, which shows that there is a strong positive correlation between autonomy and verbal ability. In addition, the findings of this study support the findings of Elekaei and Faramarzi and Tabriz (2016), which found a visible positive link between autonomy and critical thinking skills of students. In addition, the findings of this study support the findings of Fahim and Koleini (2014), who found a close relationship between critical thinking and speech skills.

Although, Zarei's (2012) research shows that correlation between vocabulary and critical thinking is not statistically meaningful. In addition, Afshar and Rahimi (2014) study the relationship between instrumental motivation, critical thinking, autonomy and academic achievement of Iranian students. The results show that the relationship between critical thinking and autonomy, instrumental motivation, and autonomy is important but there is no significant link between critical thinking and instrumental motivation.

In this case, language learners using more target languages can overtake other language learners, especially in the ability to speak verbally, which is closely related to the exposure they receive. So there are more and more questions about how autonomous language learners accept such dangers. This may partly reflect the results of our interviews with some independent participants. We have made ten students with high scores for self-esteem. Almost all respondents told us they have a lot of hearing work this week. This is in line with our previous assumption that autonomous students accept more language than non-autonomous students, which is the first language-based application, based on native speakers, interactive and experimental researchers. They further emphasized that their language teacher is easier than the wise man who creates miracles. They also discovered that they use metacognitive strategies such as planning, monitoring and evaluation. Through interviews they also found that they used technology to support language learning. The three respondents thought they should not continue to study class language. They already know how to join language learning. Therefore, there is a causal connection between the autonomy of language learners and their progress in language learning. Of course, current or almost experimental research can better convey this relationship. It is an effective way for language learners to learn independently.

To improve students' ability to speak, teachers should encourage their critical thinking skills. These skills address their ability to think through student problems and challenging learning tasks in order to fully negotiate information and provide students with more opportunities.

Research findings in this area are consistent with Wang (2009). They found that students who participated in the class of critical English speech had the greatest satisfaction with their class of dialogue. Therefore, they are more willing to participate.

Critical thinking strategies help the active listeners' participants communicate with other students by listening to the speeches of other students, judging these discussions and making the best decisions based on what is said in the dialogue. In fact, critical thinking strategies help students take into account all the characteristics of a good conversation when speaking in class. Students fully understand what other students say and what they want to interact. The results of this study showed a significant relationship between the critical level of 0.05 and oral skills $(r=0.910)$. Thus, the zero hypothesis of the study was rejected and it can be concluded that verbal ability is influenced by the ability of critical thinking. Other findings from this study showed a significant correlation $(r=0.898)$ 
when the level of importance of autonomy and verbal skills was 0.05 . Hence, the hypothesis of the study is rejected and it can be concluded that speaking skills are influenced by autonomy. Regarding the research restrictions, we can call time management. It seems that the 16 -week semester at the Iranian University is not enough for teachers to allow them to practice critical thinking and autonomous and oral skills with students. Teachers should encourage their students to use these skills beyond the classroom and use their ideas to express their criticisms with confidence. In addition, more Persian books on critical thinking and autonomy should be provided so that students benefit from the benefits of critical thinking and self-government.

\section{CONCLUSION AND IMPLiCATIONS OF THE STUDY}

The purpose of this study was to investigate the relationship between autonomy and critical thinking ability of Iranian students, the influence of student autonomy on student ability to speak and the ability to critical thinking skills to influence the languages of these languages. One finding of this study was that there was a positive correlation between the autonomy of students and students of the Iranian EFL.

Another finding of this study is that critical thinking has a significant impact on the student's oral ability. In other words, the highest autonomous students have higher scores.

In addition, another study of this study was that the degree of critical thinking of students had a significant impact on their outcomes. In other words, students with higher critical thinking skills are higher.

In recent decades, the concept of student autonomy and critical thinking has attracted the attention of many scholars and has become a popular vocabulary in the context of education. This is more attractive in language education. One of the ultimate goals is to help students become independent classes. In the EFL context, language learners typically stay behind their peers in the ESL context in their ability to control the target language, but there are many more concepts to be considered in autonomy. This study shows that in this situation, language learners with higher autonomy and critical thinking have better language skills than other low-level students of autonomy and critical criticism. As described, this roots are in the zeal and motivation of students who may be the result of autonomous student awareness in the language education process. Of course this is true of other language skills as well. However, student autonomy does not imply that teachers become impossible, but this means helping students to be more dependent or less dependent on teaching practices. Therefore, the way the educational system leads to the development of student autonomy and critical thinking has become increasingly prominent. This seems to be a challenging field that requires civil servants to plan, implement and monitor. In this regard, the teacher training program should include students, novices and teachers with experience in this issue and develop methods and solutions. We believe that independent education will not help us to achieve our goals, to which lifelong learning is our goal and appreciate. Of course, this study is not without restriction. To better explain the potential role of autonomous and critical thinking in any language learning activity, the need for quality methods and research is felt deeply. Case studies and ethnography are really useful in this area. Quantitative studies with a sufficient number of participants and broader contextual coverage will reveal the importance of autonomy in language learning and critical thinking.

The findings and results of this study may have an impact on language teachers, English students and English school leaders.

The results are beneficial to a variety of individuals and organizations because they can benefit from the findings.

- Educational decision makers should consider the applicability of autonomy and critical thinking.

- Students and students should be encouraged to speak the target language.

- Students should work in pairs and groups to improve their speaking ability.

- The process of English teaching supervisors should promote oral skills.

\section{REFERENCES}

[1] Ablard, K., \&Lipschultz, R. (1998). Self - regulated learning in high achieving students: Relations to advanced reasoning, achievement goals, and gender. Journal of Educational Psychology, 90 (2), 94-101. 
[2] Afshar, H.S., Rahimi, A., \&Rahimi, M. (2014). Instrumental motivation, critical thinking autonomy and academic achievement of Iranian EFL learners. Issues in Educational Research, 24 (3), 281-298.

[3] Arkoç, E. Ş. (2008). The impact of learner autonomy on the success of listening comprehension. Doctoral dissertation, Trakya University.

[4] Arum, R., \&Roska, J. (2011). Academically Adrift; Limited Learning on College Campuses. Chicago: University of Chicago Press.

[5] Bagheri, M.S. \&Bazrafkan, N. (2014). The relationship between critical thinking, autonomy and writing skill of the Iranian EFL learners. International Journal of Language Learning and Applied Linguistics World, 7 (3), 379-392.

[6] Barghi, E., \&Zangoei, A. (2014). Learners' language learning style preferences and its relationship with their critical thinking ability in an Iranian EFL context. International Journal of Language Learning and Applied Linguistics World,6(2),269-280.

[7] Benson, P., \&Voller, P. (1997). Autonomy and independence in language learning. New York: Addison Wesley Longman Limited.

[8] Benson, P. (2001). Teaching and researching autonomy in language learning. London: Longman.

[9] Bora, F. D. (2012). The impact of emotional intelligence on developing speaking skills: From brain-based perspective. Procedia - Social and Behavioural Sciences, 46, 2094 - 2098.

[10] Breeze, R. (2002). Attitudes towards learner autonomy among Spanish University students. Atlantis, 24(2), 23-36.

[11] Brown, H. D. (1994). Teaching by principles: an interactive approach to language pedagogy. Englewood Cliffs, NJ: Prentice Hall Regent.

[12] Burns, A., \& Joyce, H. (1997). Focus on Speaking. Sydney: National Center for English Language Teaching and Research.

[13] Corno, L., \& Mandiach, E.B. (1983). The role of cognitive engagement in classroom learning and motivation. Educational Psychologist, 18, 88-108.

[14] Dafei, D. (2007). An exploration of the relationship between learner autonomy and English proficiency. Asian EFL Journal, 24, 6-8.

[15] Dam, L. (1995). Learner autonomy 3: From theory to classroom practice. Dublin: Authentic.

[16] Dickinson, L. (1995). Autonomy and motivation: A literature review. System, 23(2), 165-174.

[17] Elekaei, A., Faramarzi, S., \& Tabrizi, H. H. (2016). Autonomy, critical thinking and listening comprehension ability of Iranian EFL learners. International of Applied Linguistics and English Literature, 5 (2), 40-48.

[18] Facione, P. A. (2007). Critical Thinking: What it is and why it counts. Insight assessment, 9, 1-28.

[19] Faerch, C., \& Kasper, G. (1983). Plans and strategies in foreign language communication. In

[20] Firch, C. \& Kasper, G. (eds.) Strategies in inter language communication, London: Longman, 20-60.

[21] Fahim, M., \&Haghighi, M. (201 4). The relationship between critical thinking ability of Iranian EFL learners and their academic self-regulation. International Journal of Language Learning and Applied Linguistics World, 5(3), 390-400.

[22] Fahim, M., \&Koleini, A. (2014). The relationship between critical thinking ability of Iranian EFL learners and their speaking skills. International Journal of Language Learning and Applied Linguistics World, 5(4), 233-241.

[23] Folse, K. (2006). The art of teaching speaking. Michigan: Michigan University Press.

[24] Fulcher, G. (2003). Testing second language speaking. NewYork: Pearson Longman.

[25] Hall, G. (2011). Exploring English language teaching. Language in Action, New York.

[26] Holec, H. (1981). Autonomy and foreign language learning. Oxford: Pergamon (first published [1969], Strasbourg: council of Europe, 3).

[27] Joiner, R., \& Jones, S. (2003). The effect of communication medium on argumentation and the development of critical thinking. International Journal of Educational Research, 23(4), 1364-1375.

[28] Little, D. (1991). Learner autonomy 1: definitions, issues, and problems. Dublin: Authentik.

[29] Little, D. (1 995). Learning as dialogue: The dependence of learner autonomy on teacher autonomy. System, 23(2), 175-182.

[30] Luoma, S. (2004). Assessing speaking. NewYork, Cambridge University Press.

[31] Malmir, A., \&Shoorcheh, S. (2012). An investigation of the impact of teaching critical thinking on Iranian EFL learners' speaking skill. Journal of Language Teaching and Research, 3(40), 608-617.

[32] McMillan, J. H. (1987). Endowing college students' critical thinking: A review of studies. Research in Higher Education, 26 (1), 3-29.

[33] Myers, B. E., \& Dyer, J. E. (2006). The consequences of student learning style on critical thinking skill. Journal of Agricultural Education, 4(7), 43-52. 
[34] Nation, I. S. P., \& Macalister, J. (2010). Language curriculum design. New York: Rout ledge

[35] Nosratinia, M., Asiabar, M. G., \&Sarabchian, E. (201 4). The relationship between Iranian EFL learners' languagelearning strategies and critical thinking. International Journal of Language and Applied Linguistics World, 5(2), 335-345.

[36] Nosratinia, M., \&Zaker, A. (2013). Autonomous learning and critical thinking: Inspecting the association among EFL learners. Paper presented at the First national Conference on Teaching English, Literature, and translation, Shiraz University, Shiraz, Iran. Retrieved from http://www.civilica.com/Paper-TELT01-TELT01_226.html

[37] O’Maley, J., \&Chamot, A. (1990). Learning strategies in second language acquisition. Cambridge: Cambridge University Press.

[38] Oxford, R. L. (1990). Language learning strategies: What every teacher should know. Boston: Heinle\&Heinle.

[39] Paul, R.W. (1985). The Critical Thinking Movement: A Historical Perspective. National Forum, 65(1), 2-3, 32.

[40] Paul, R., Elder, L., \& Bartell, T. (1997). Taken from the California Teacher Preparation for Instruction in Critical Thinking: Research Findings and Policy Recommendations: State of California.

[41] Ramezani, R., Larsari, E., \&Kiasi, M. (2016).The relationship between critical thinking and EFL learners'speaking ability. English language teaching, 9(6), 189-198.

[42] Rezaei, F. S., Karbalaei, A., \&Afraz, S. (2013). The effect of vocabulary strategy training among autonomous and non-autonomous learners in Iranian EFL context. European Online Journal of Natural and Social Sciences, 2(2s), 35.

[43] Sanavi, V. R., \&Tarighat, S. (2014). Critical thinking and speaking proficiency: A Mixed- Method Study. Theory and Practice in Language Studies, 4(1), 79-87.

[44] Seligson, P. (1997). Helping students to speak. Richmond Publishing.

[45] Tabatabaei, O., \&Parsafar, S. M. (2012). The effect of self-directed learning on critical thinking of Iranian EFL learners. Journal of Educational and Social Research, 2(2), 55-64.

[46] Thanasoulas, D. (2000). Autonomy and learning: An epistemological approach. Applied Semiotics, 4(10), 115 131.

[47] Thornbury, S. (2007). How to teach speaking. Pearson Longman.

[48] Ur, P. (1996). A course in language teaching: Practice and theory. Cambridge: Cambridge University Press.

[49] Valadi, A., \&Rashidi, V. (2014).How are language autonomy and their oral language proficiency related in an EFL context? International Journal of Language learning and Applied Linguistics World, 7(1), 124-131.

[50] Van Duzer, C. (1997). Improving ESL learners' listening skills: At the workplace and beyond.

[51] Washington, DC: Project in Adult Immigrant Education and National Clearing house For ESL Literacy Education.

[52] Wagner, R. K. (1997). Intelligence, Training, and Employment. American Psychologist, 52(10), 1059-1069.

[53] Warnick, B., \& Inch, E. (1994). Critical Thinking and Communication (2nd ed.), NewYork: Macmillan.

[54] Watson, G., \& Glaser, E.M. (1980). Watson-Glaser Critical Thinking Appraisal manual.

[55] Dallas, TX: The Psychological Corporation.

[56] Wenden, A. (1998). Learner strategies for learner autonomy. Great Britain: Prentice Hall.

[57] Willingham, D. T. (2007). Critical thinking: Why is it so hard to teach? American Educator, 8-19.

[58] Zarei, A. A. (2012). The relationship between critical thinking and L2 grammatical and lexical knowledge. English Linguistics Research, 1(1), 104-110.

[59] Zhang, L., \& Li, X. (2004). A comparative study on learner autonomy between Chinese students and West European students. Foreign Language World, 24(4), 15-23

[60] Zimmerman, B. J., \&Risemberge, R. (1997). Self - regulatory dimensions of academic learning and motivation. In Phye, G. D. (Ed.). Handbook of academic learning (pp. 105-125).

Citation: Najme Bagheri. "Critical Thinking and Autonomy in Speaking Ability: A Case Study" International Journal on Studies in English Language and Literature (IJSELL), vol 6, no. 5, 2018, pp. 73-83. doi:http://dx.doi.org/10.20431/2347-3134.0605009.

Copyright: (c) 2018 Authors. This is an open-access article distributed under the terms of the Creative Commons Attribution License, which permits unrestricted use, distribution, and reproduction in any medium, provided the original author and source are credited. 